\title{
IDENTIFIKASI DAN MANAJEMEN KENDARAAN DI ITS PADA PERANGKAT BERGERAK DENGAN TEKNOLOGI QR-CODE
}

\author{
Henning Titi Ciptaningtyas ${ }^{1)}$, Bambang Setiawan ${ }^{2)}$ Muhammad $^{3)}$ \\ 1,3 Jurusan Teknik Informatika, ${ }^{2}$ Jurusan Sistem Informasi \\ Fakultas Teknologi Informasi, Institut Teknologi Sepuluh Nopember \\ Kampus ITS, Sukolilo, Surabaya 60111 \\ Telp : (031) 5939214, Fax : (031) 5913804
}

E-mail: henning@if.its.ac.id ${ }^{1)}$

\begin{abstract}
Cars and motorcycles are widely used transportation in ITS campus. Large number of vehicles in ITS makes the Security and Safety Unit (SKK) feel hard to recognize the vehicle ownerships. It makes ITS campus vulnerable to theft. To reduce the risk of theft, we propose vehicle identification using QRcode. The licence plate number of the vehicle is added with a string, hashed with MD5 function, and the output string will be converted to QRcode. Using android mobile devices, the data is read from QRcode and sent to server to get the vechicle and owner details. From testing the performance of the system using different data connection(Wifi, 2G, 3G), noise factor, light factor, rain factor, and distance factor, we can conclude that the system decrease 50\% time needed for identify vehicles and increase the security of ITS environment by giving the vechicle and owner details to SKK.

\section{Abstrak}

Mobil dan motor adalah moda transportasi yang paling banyak digunakan di kampus ITS Surabaya. Banyaknya jumlah kendaraan di kampus ITS membuat Satuan Keamanan dan Keselamatan (SKK) ITS sulit mengenali kepemilikan kendaraan, apakah milik civitas akademika ITS atau milik masyarakat umum. Hal ini menyebabkan keamanan kampus ITS menjadi rawan terhadap pencurian kendaraan. Metode yang diusulkan untuk mengurangi resiko pencurian adalah identifikasi kendaraan dengan menggunakan QRcode. Plat nomor kendaraan akan ditambahkan dengan kata tertentu, dihash menggunakan MD5, dan hasilnya akan dikonversikan dalam bentuk QRcode. Dengan bantuan perangkat mobile berbasis android, data akan dibaca dari QRcode dan dikirim ke server untuk mendapatkan detail kendaraan dan detail pemilik kendaraan. Setelah dilakukan uji coba performa sistem menggunakan koneksi data yang berbeda (WiFi, 2G, 3G), efek derau, efek cahaya, efek air, dan jarak pembacaan QRcode, dapat disimpulkan bahwa aplikasi ini mempersingkat waktu identifikasi kendaraan sebesar 50\% dan meningkatkan keamanan di lingkungan ITS karena SKK bisa memeriksa detail kendaraan dan detail pemilik kendaraan.
\end{abstract}

Kata kunci: android, keamanan kendaraan, QRcode, identifikasi.

\section{PENDAHULUAN}

Kendaraan bermotor merupakan salah satu moda transportasi yang banyak digunakan. Dengan kendaraan bermotor, manusia dapat berpindah dari satu tempat ke tempat lainnya dengan cepat. Tidak heran jika setiap orang mempunyai minimal satu buah motor untuk mendukung kegiatan sehari-harinya, khususnya civitas akademika Institut Teknologi Sepuluh Nopember (ITS). Di kampus ITS jumlah kendaraan bermotor sangat banyak. Dengan banyaknya jumlah kendaraan bermotor yang ada di kampus ITS, menjadikan Satuan Keamanan dan Keselamatan (SKK) sulit mengenali kendaraan milik civitas akademika ITS atau kendaraan milik masyarakat umum.
Pada saat-saat tertentu, banyak pula kendaraan yang parkir tidak pada tempatnya, seperti pada hari Jum'at (pada saat sebelum dan setelah shalat Jumat) serta pada hari libur nasional saat parkiran ditutup (pada hari Sabtu, Minggu, serta hari besar lainnya). Bahkan pada saat libur panjang, ada kasus di mana kendaraan ditinggal di tempat parkir resmi ataupun tidak resmi selama 2 minggu dan pemiliknya tidak diketahui. Oleh karena itu, ITS membutuhkan sebuah teknologi yang dapat mengidentifikasi pemilik kendaraan tersebut. Untuk menjaga keamanan kampus, SKK ITS biasanya hanya memeriksa kendaraan yang keluar ITS dengan langkah sebagai berikut:

- Pengendara mengeluarkan STNK dari dompet. 
- SKK memeriksa STNK pengendara dan mencocokkannya plat nomor kendaraan.

- Pengendara memasukkan STNK ke dompet

Proses tersebut membutuhkan waktu rata-rata 30-40 detik. Hal ini masih bisa diakali pencuri dengan cara mencopot plat nomor kendaraan dan memasang plat baru yang sesuai dengan STNK yang dibawa pencuri. Dari informasi yang diperoleh dari SKK ITS, pada awal tahun 2013 telah terjadi lebih dari 10 kasus pencurian sepeda motor di lingkungan ITS. Hampir semua kendaraan tersebut di parkir tidak pada tempat yang telah disediakan. Dengan bantuan perangkat lunak yang dapat mengidentifikasi kendaraan yang keluar masuk ITS dan kendaraan yang parkir, diharapkan hal ini dapat meningkatkan tingkat keamanan di lingkungan ITS.

Sebelumnya Zeydin Pala dan Nihat Inanc sudah melakukan penelitian tentang sistem Check in Check out parkir menggunakan RFID yang terhubung dengan internet danserver basis data. Dengan bantuan RFID dan server basis data, sistem parkir dapat berjalan lebih lancar (Pala, et al., 2007). Kekurangan utama dalam pemanfaatan RFID adalah tidak portabel.

Metode lain yang lazim digunakan untuk mengenali sebuah objek selain dengan RFID adalah barcode. Namun barcode memiliki kelemahan, yaitu data yang terdapat pada barcode tidak dapat direkam apabila ada gangguan dari objek lain, contohnya barcode pada buku yang dilapisi oleh sampul buku. Seiring dengan berkembangnya teknologi, terdapat sebuah variasi baru dari barcode yang dinamakan QR Code. QR Code adalah sebuah simbol dua dimensi. QR Code pertama kali digunakan untuk mengontrol produksi dari suku cadang otomotif di Jepang. Beberapa kelebihan yang dimiliki oleh QR Code adalah dapat menyimpan huruf hiragana, katakana dan kanji, kecepatan dalam membaca, tahan terhadap kerusakan atau gangguan dari objek lain yang terjadi pada simbol (synthesis journal, 2008).

ITS membutuhkan sebuah media bersifat portabel dan murah yang dapat mengidentifikasi kendaraan yang keluar masuk serta mengelola kendaraan yang parkir di kampus ITS. Identifikasi dilakukan dengan cara mengenali kendaraan dan mencatat waktu masuk dan keluar dari kampus. Sedangkan manajemen kendaraan akan dilakukan dengan cara mencatat kendaraan yang parkir tidak pada tempatnya ke server basis data sehingga akan memudahkan SKK dalam menindaklanjutinya.
Pada penelitian ini dibuat sebuah perangkat lunak yang dapat digunakan untuk mengidentifikasi dan memanajemen kendaraan di lingkungan ITS menggunakan perangkat bergerak dengan teknologi QR Code.

\section{METODOLOGI}

Dalam penelitian ini digunakan $\mathrm{QR}$ code, $\mathrm{MD}$ 5, dan JSON.

\subsection{QRcode}

QR Code adalah bentuk 2D dari barcode. Contoh QR Code dapat dilihat pada Gambar 2. QR Code dikembangkan oleh Denso-Wave pada tahun 1994 (QR Codes in Education, 2010). QR adalah sebuah singkatan dari Quick Response. QR Code dapat dibaca oleh perang-kat bergerak yang dilengkapi kamera dan $Q R$ Scanner. QR Code sangat populer karena memiliki kapasitas data yang besar dengan ukuran cetak yang kecil. Kapasitas data yang mampu disimpan oleh QR Code hingga 7.089 karakter numerik, 4.296 karakter alfanumerik, 2.953 binary bytes, 1.817 karakater Kanji, jauh lebih tinggi daripada yang lainnya seperti PDF417, DataMatrix dan Maxi Code.

QR Code menyimpan informasi secara vertikal dan horizontal (DENSOWAVE, 2013). QR Code dapat dibaca dibaca dari segala arah dalam $360^{\circ}$ melalui pola deteksi posisi yang terletak pada tiga sudut seperti yang terlihat pada Gambar X. Sebuah QR Code dapat dibaca walaupun terdapat distorsi. Error correction capability terhadap debu atau kerusakan bisa mencapai 30\% untuk QR code Level H. Dengan adanya QR Code dan ponsel pintar, memungkinkan pengguna dapat berinterkasi secara lebih cepat dan efisien dengan konten yang disimpan pada QR Code (Gambar 1). Pengguna juga dapat membuat sendiri QR Code dengan mengunjungi salah satu dari situs-situs yang menyediakan QR Code generator. Dalam penelitian ini, QRcode digunakan untuk menyimpan data plat nomor kendaraan bermotor di ITS dan berfungsi sebagai alat identifikasi kendaraan bermotor (pengganti STNK). Untuk membuat dan membaca string yang di-embed pada QR Code, aplikasi akan menggunakan free library yang bernama ZXing (Zebra Crossing).

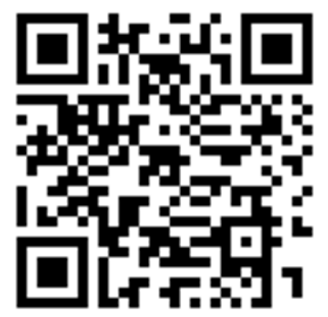

Gambar 2. QR Code 
Ciptaningtyas, dkk., Identifikasi dan Manajemen Kendaraan di ITS pada Perangkat

\subsection{5}

MD5 adalah algoritma message digest yang menggunakan fungsi hash untuk menghasilkan output pesan bernilai tetap yaitu sebanyak 128 bit untuk semua panjang input (Rivest, 1992). MD5 bisa dipakai sebagai checksum untuk mendeteksi perubahan file, menyimpan password di database, tanda tangan digital. Dalam penelitian ini, MD5 digunakan untuk menyembunyikan angka asli dari plat nomor kendaraan sebelum dikonversikan menjadi QRCode.

\subsection{JSON}

JSON atau JavaScript Object Notation adalah format pertukaran data yang ringan, mudah dibaca dan ditulis oleh manusia, serta mudah diterjemahkan dan dibuat oleh komputer (JSON, 2013). Format ini dibuat berdasarkan bagian dari Bahasa Pemprograman JavaScript, Standar ECMA-262 Edisi ke-3 - Desember 1999. JSON merupakan format teks yang tidak bergantung pada bahasa pemprograman apapun karena menggunakan gaya bahasa yang umum digunakan oleh programmer keluarga C. Oleh karena sifat tersebut, menjadikan JSON ideal sebagai bahasa pertukaran data.

Struktur dari JSON terdiri dari dua, yaitu kumpulan pasangan nama atau nilai yang pada beberapa bahasa hal ini dinyatakan sebagai objek, record, struktur, dictionary, table hash, daftar berkunci atau associative array. Struktur yang kedua adalah daftar nilai terurutkan yang pada banyak bahasa hal ini dinyatakan sebagai array, vector, daftar atau urutan. Struktur data ini disebut sebagai struktur data universal. Pada dasarnya, semua bahasa pemprograman modern mendukung struktur data ini dalam bentuk yang sama maupun berlainan. Hal ini pantas disebut demikian karena format data mudah ditukarkan dengan bahasa pemrograman lain yang juga berdasarkan pada struktur data ini. Dalam penelitian ini JSON digunakan untuk melakukan pertukaran data antar perangkat bergerak yang digunakan untuk mengidentifikasi kendaraan dan server aplikasi.

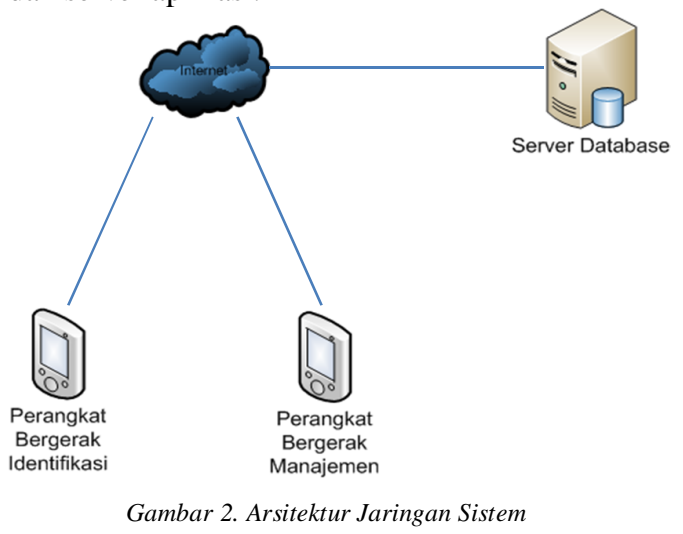

Sistem identifikasi dan manajemen kendaraan ini terdiri dari 2 aplikasi seperti yang terlihat pada Gambar 2. Aplikasi pertama adalah aplikasi identifikasi pada klien. Aplikasi identifikasi memiliki fungsi untuk mengidentifikasi kendaraan yang keluar masuk lingkungan ITS. Kendaraan diidentifikasi berdasarkan plat nomor kendaraan. Permasalahan yang terdapat pada plat nomor kendaraan yang disimpan di dalam sebuah QR Code adalah bagaimana agar plat nomor tersebut tidak dapat dimengerti oleh orang lain. Untuk mengantisipasi hal tersebut, maka plat nomor yang akan dibuat QR Codenya dapat disembunyikan dengan cara menambahkan sebuah string rahasia, dan kemudian dihash dengan algoritma MD5. Dengan cara ini, diharapkan level keamanan aplikasi dapat ditingkatkan.

Sebagai contoh sebuah kendaraan dengan plat nomor "N 534 KF" apabila di-hash dengan algoritma MD5 akan menghasilkan "81be939212671b61c3e6534fd67be797”. Tentu saja hal ini dapat dimengerti oleh pihak lain. Tetapi apabila plat nomor "N $534 \mathrm{KF}$ " kita tambahkan sebuah string "IF" maka akan menghasilkan hasil MD5 yang berbeda, yaitu "8872f7506e5df6286c270c774311fd96".

Data plat nomor kendaraan yang ditambahkan dengan kata tertentu dan di-hash menggunakan MD5 akan dikonversikan dalam bentuk QR code. Dengan bantuan perangkat bergerak, data akan dibaca dari QRcode dan dikirim ke server untuk mendapatkan detail kendaraan dan detail pemilik kendaraan. Sedangkan aplikasi yang kedua adalah aplikasi manajemen pada server yang memiliki fungsi untuk melaporkan kendaraan yang parkir tidak pada tempatnya.

Aplikasi ini dapat berjalan di jaringan intranet maupun internet Untuk mempercepat proses pengiriman dan penerimaan data disarankan untuk menggunakan jaringan intranet, mengingat jaringan internet sangat tergantung dari kekuatan sinyal dan kekuatan sinyal di beberapa tempat berbeda. Perangkat lunak yang digunakan untuk membangun aplikasi ini adalah:

a. ADT windows bundle package yang digunakan untuk membangun aplikasi pada perangkat bergerak Android.

b. Microsoft Windows 8 32-bit sebagai sistem operasi pada server.

c. XAMPP 1.7.7 sebagai Apache HTTP Server dan MySQL Basis data.

d. SQLyog Enterprise sebagai aplikasi klien yang digunakan untuk mengakses basis data.

e. ZXing (Zebra Crossing) digunakan untuk membaca string yang di-embed pada QR Code. 


\subsection{Alur Proses}

Alur proses akan memperlihatkan urutan proses yang dilakukan oleh aplikasi.

a. Alur proses pendaftaran

Untuk mendaftarkan pengendara dan kendaraan, alurnya adalah sebagai berikut:

\begin{tabular}{|c|}
\hline Pemilik kendaraan ke kantor pusat SKK ITS \\
\hline $\begin{array}{c}\text { SKK mendaftarkan data pemilik kendaraan } \\
\text { pada aplikasi server }\end{array}$ \\
\hline $\begin{array}{c}\mathrm{b} \\
\text { SKK mendaftarkan data kendaraan pada } \\
\text { aplikasi server }\end{array}$ \\
\hline $\begin{array}{l}\text { Aplikasi server menambah string "IF" pada } \\
\text { data nomor kendaraan }\end{array}$ \\
\hline $\begin{array}{c}\mathrm{Sp} \\
\begin{array}{c}\text { Aplikasi server mengenkripsi data string } \\
\text { dengan fungsi M D5 }\end{array}\end{array}$ \\
\hline$\sqrt{5}$ \\
\hline Aplikasi server memproduksi QR code \\
\hline $\begin{array}{c}\text { Pemilik menempel stiker QR code pada } \\
\text { bagian depan kendaraan }\end{array}$ \\
\hline
\end{tabular}

b. Alur proses identifikasi kendaraanı Identifikasi kendaraan dilakukan oleh SKK dengan menggunakan aplikasi klien yang ada di perangkat bergerak berbasis android dan berdasarkan data dari server. Hal ini dilakukan baik untuk kendaraan masuk maupun kendaraan keluar ITS. Alurnya adalah sebagai berikut:

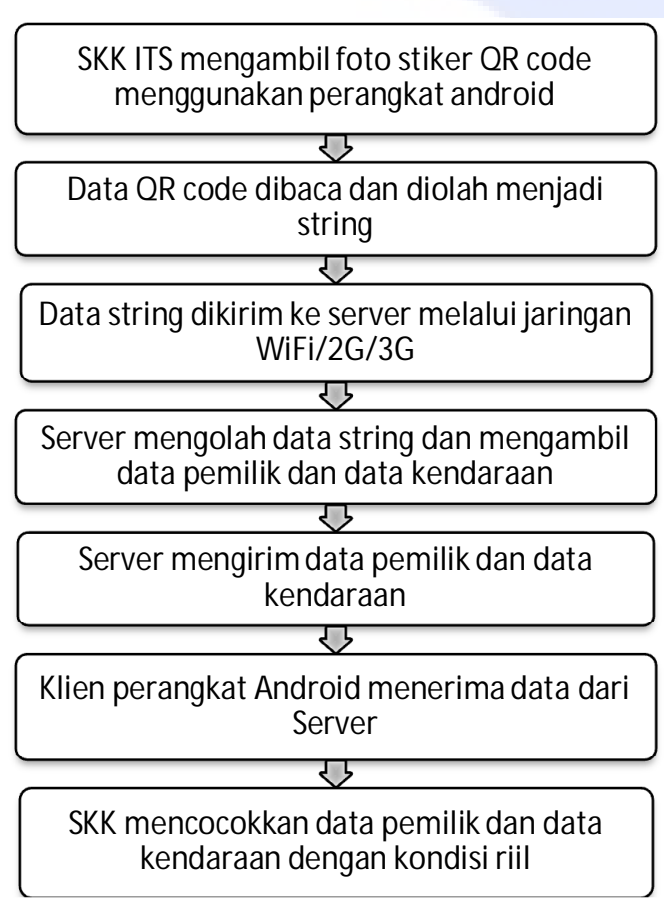

\subsection{Fitur Pada Klien}

Fitur yang tersedia pada klien adalah:

a. Halaman Utama: Digunakan untuk identifikasi kendaraan masuk dan kendaraan keluar seperti pada Gambar 3.

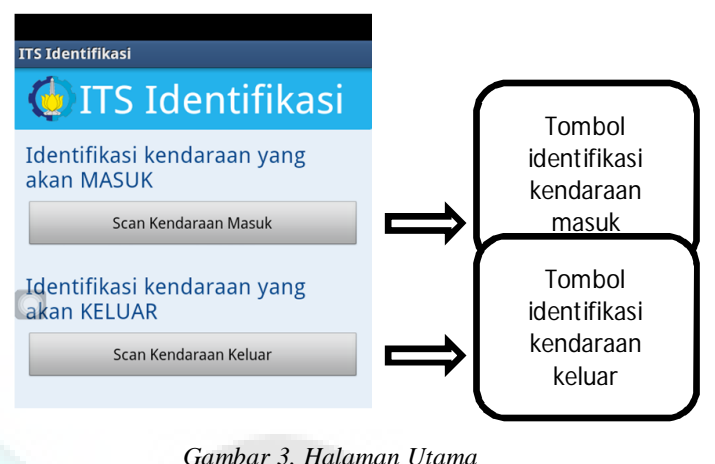

b. Membaca QR Code: Klien dapat membaca string yang terdapat pada QR Code seperti pada Gambar 4.

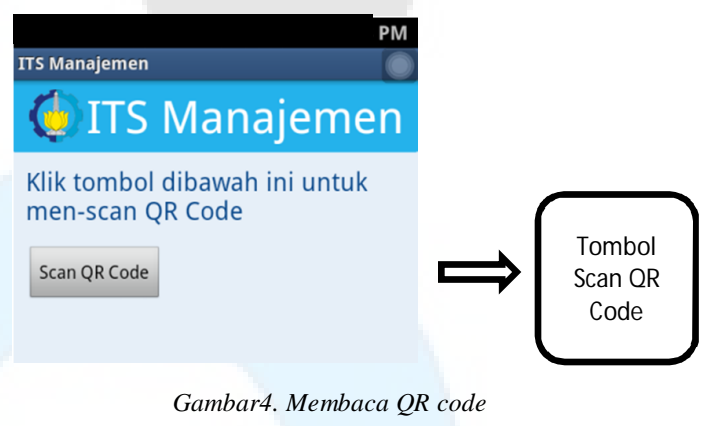

c. Mengirim data masukan: Klien dapat mengirim data masukan ke server berupa hasil dari pembacaan QR Code dan keterangan pelaporan pelanggaran (Gambar 5).

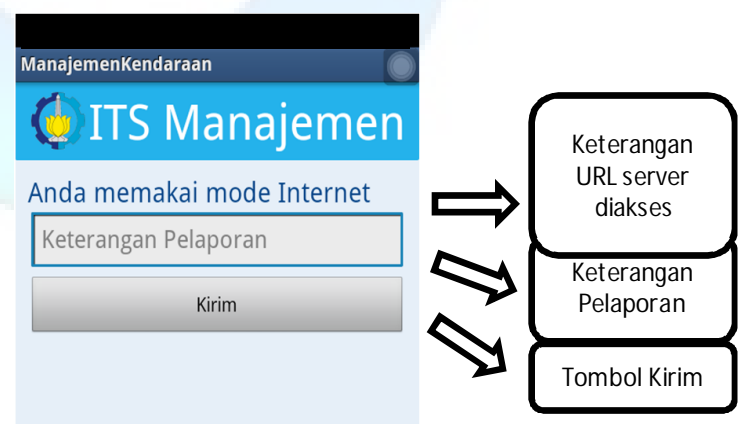

Gambar 5. Klien Mengirim Data

d. Menerima data hasil proses: Klien dapat menerima data yang dikirim oleh server.

e. Menampilkan data: Klien dapat menampilkan hasil proses yang dikirim oleh server. Data bisa berupa detil kendaraan seperti pada Gambar 6 atau foto kendaraan seperti pada Gambar 7. 
Ciptaningtyas, dkk., Identifikasi dan Manajemen Kendaraan di ITS pada Perangkat

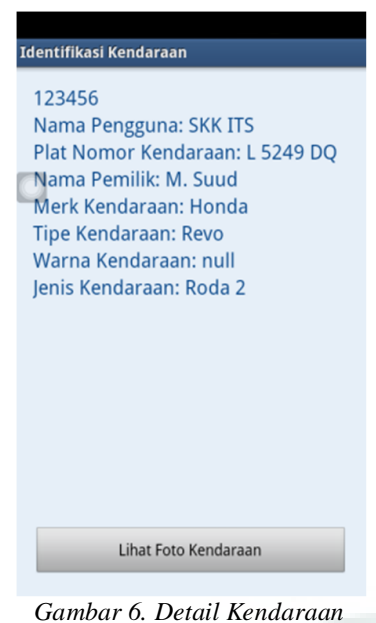

Pendaftaran Pengguna Kendaraan

Biodata Diri

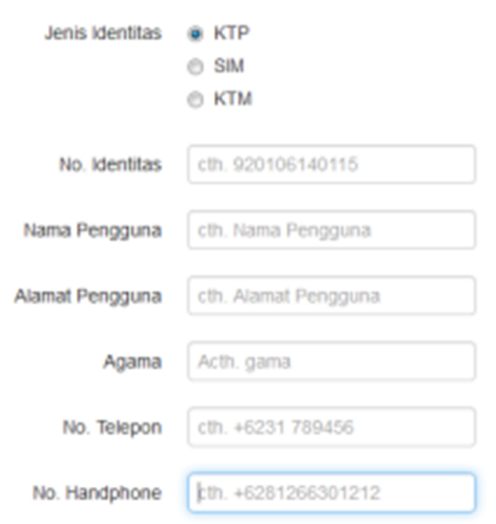

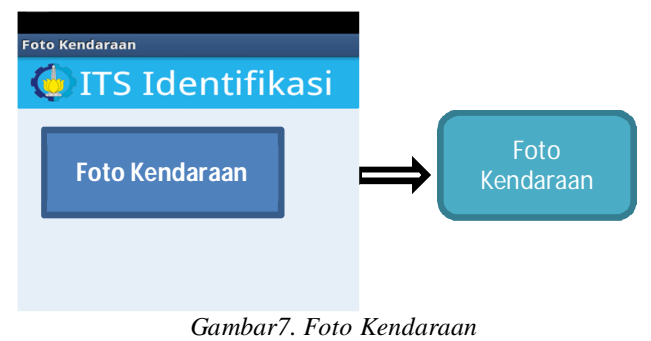

\subsection{Fitur Pada Server}

Fitur yang tersedia pada server adalah:

a. Mendaftarkan pemilik kendaraan seperti pada Gambar 8

b. Mendaftarkan kendaraan seperti pada Gambar 9

c. Generate QR Code untuk setiap kendaraan seperti pada Gambar 10

Unggah Foto Kendaraan

Unggah Foto

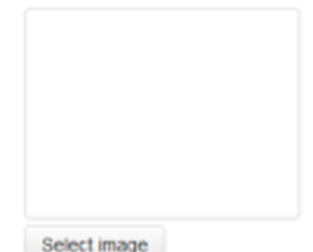

Daftar

Gambar 8. Mendaftarkan Pemilik Kendaraan

Pendaftaran Kendaraan

Data STNK Kendaraan

Kendaraan yang akan didaftar adalah milk : SKK ITS123456

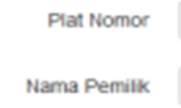

Merk Kendaraan

Tpe Kendaraan

Wama Kendaraan

Roda Kendaraan

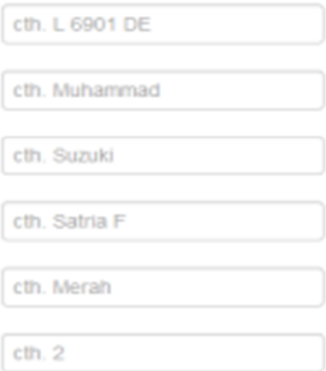

Unggah Foto Kendaraan

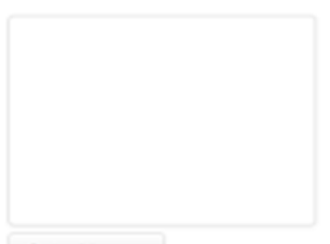

Select image

\section{Daftar}

Gambar 9. Mendaftarkan Kendaraan 
riset.ajk.if.its.ac.id/itsparking/qrcode/cetakqrcode.php

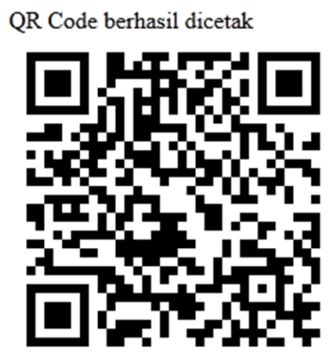

$\underline{\text { Kembali }}$

Gambar 10. Generate QR code

d. Mendapatkan data hasil proses sesuai data masukan: Melalui fitur ini klien akan menerima data hasil proses server berupa detail pemilik kendaraan sesuai dengan data masukan yang dikirim klien.

e. Mencatat waktu kendaraan masuk atau keluar: Melalui fitur ini server akan mencatat waktu masuk dan keluar kendaraan yang berhasil diidentifikasi. Pencatatan waktu didasari oleh data masukan berupa keterangan identifikasi yang dikirim oleh klien.

f. Menyimpan data masukan berupa pelaporan kendaraan ke basis data: Melalui fitur ini, server akan menyimpan data masukan berupa pelaporan kendaraan yang parkir tidak pada tempatnya ke basis data.

g. Menampilkan data sesuai hak akses aplikasi seperti pada Gambar 11

\section{HASIL dan PEMBAHASAN}

Uji coba yang dilakukan adalah uji coba performa sistem menggunakan koneksi data yang berbeda (WiFi, 2G, 3G), efek benda asing, efek cahaya, efek air, dan jarak pembacaan QRcode.

Uji coba performa ini dilakukan untuk mengetahui kecepatan klien mengirim data masukan sampai klien dapat menampilkan data hasil proses pada aplikasi identifikasi. Lingkungan uji coba response time terdiri dari:

a. 1 unit komputer server yang akan menerima data masukan dan mengirim data hasil proses ke klien.

b. 1 unit ponsel pintar yang akan membaca QR Code dan mengirimkan data masukan ke server seperti pada Gambar 13.

c. 1 buah $\mathrm{QR}$ Code yang dicetak pada kertas stiker seperti pada Gambar .

d. Provider tri (3) dengan paket data Rp. 35.000 untuk kuota 500MB.

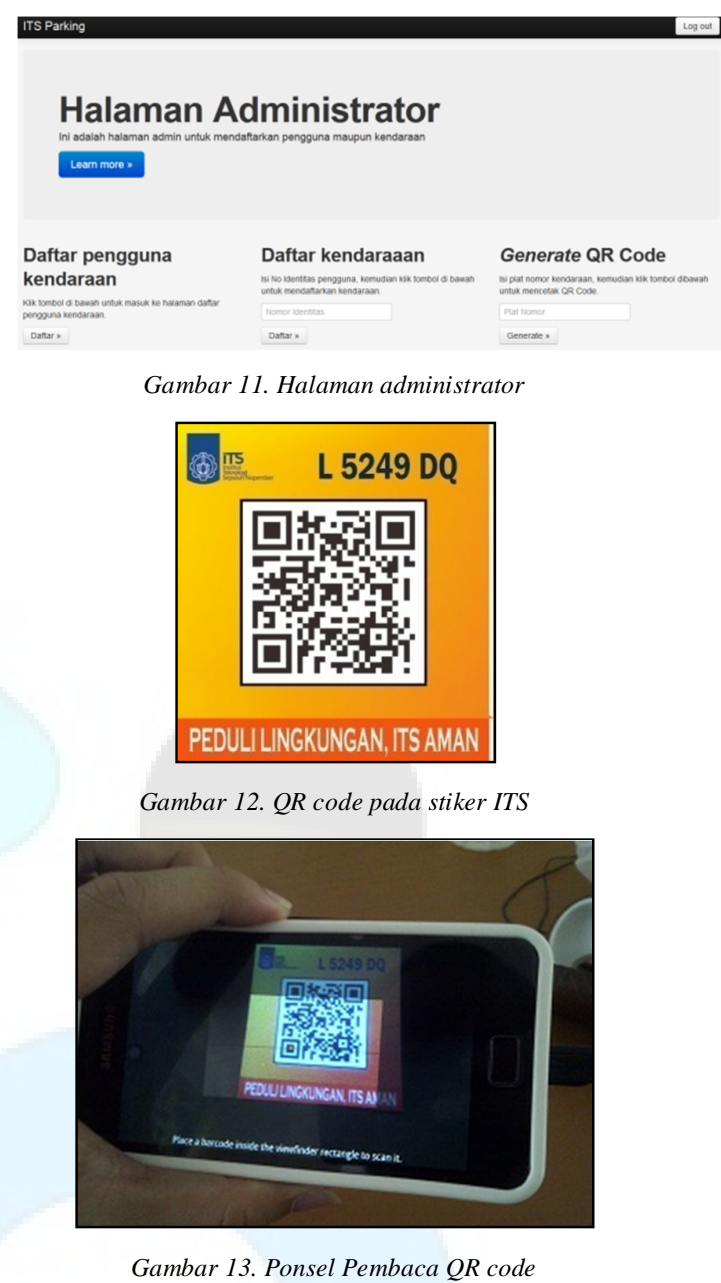

Uji coba performa akan dilakukan pada 3 kondisi, yaitu: klien akan terkoneksi dengan Wi-Fi intranet ITS, klien akan menggunakan koneksi paket data 3G, klien akan menggunakan paket 2G. Pada uji coba menggunakan koneksi Wi-Fi intranet seperti pada Tabel 14, rata-rata response time adalah $221.5 \mathrm{~ms}$ dengan range kekuatan sinyal Wi-Fi adalah -59 dBm sampai $46 \mathrm{dBm}$. Dalam uji coba ini, indikator sinyal Wi-Fi pada perangkat bergerak adalah penuh.

Tabel 14. Uji Coba Menggunakan Wi-Fi

\begin{tabular}{ll}
\hline Kekuatan Sinyal Wi-Fi & Response Time \\
\hline$-50 \mathrm{dBm}$ & $350 \mathrm{~ms}$ \\
$-59 \mathrm{dBm}$ & $238 \mathrm{~ms}$ \\
$-57 \mathrm{dBm}$ & $215 \mathrm{~ms}$ \\
$-56 \mathrm{dBm}$ & $274 \mathrm{~ms}$ \\
$-50 \mathrm{dBm}$ & $185 \mathrm{~ms}$ \\
$-52 \mathrm{dBm}$ & $198 \mathrm{~ms}$ \\
$-46 \mathrm{dBm}$ & $145 \mathrm{~ms}$ \\
$-51 \mathrm{dBm}$ & $194 \mathrm{~ms}$ \\
$-53 \mathrm{dBm}$ & $178 \mathrm{~ms}$ \\
$-57 \mathrm{dBm}$ & $238 \mathrm{~ms}$ \\
\hline
\end{tabular}


Tabel 2. Uji Coba Menggunakan Paket Data 3G

\begin{tabular}{ll}
\hline $\begin{array}{c}\text { Kekuatan Sinyal Paket } \\
\text { Data 3G }\end{array}$ & Response Time \\
\hline$-75 \mathrm{dBm}$ & 4 detik $535 \mathrm{~ms}$ \\
$-77 \mathrm{dBm}$ & 2 detik $37 \mathrm{~ms}$ \\
$-79 \mathrm{dBm}$ & 3 detik $792 \mathrm{~ms}$ \\
$-77 \mathrm{dBm}$ & 5 detik $734 \mathrm{~ms}$ \\
$-77 \mathrm{dBm}$ & 3 detik $52 \mathrm{~ms}$ \\
$-77 \mathrm{dBm}$ & 3 detik $937 \mathrm{~ms}$ \\
$-79 \mathrm{dBm}$ & 4 detik $168 \mathrm{~ms}$ \\
$-77 \mathrm{dBm}$ & 1 detik $933 \mathrm{~ms}$ \\
$-75 \mathrm{dBm}$ & 3 detik $365 \mathrm{~ms}$ \\
$-75 \mathrm{dBm}$ & 3 detik $793 \mathrm{~ms}$ \\
\hline
\end{tabular}

Tabel 3. Uji Coba Menggunakan Paket Data 2G

\begin{tabular}{ll}
\hline $\begin{array}{c}\text { Kekuatan Sinyal Paket } \\
\text { Data 2G }\end{array}$ & Response Time \\
\hline$-78 \mathrm{dBm}$ & 2 detik $560 \mathrm{~ms}$ \\
$-75 \mathrm{dBm}$ & 2 detik $719 \mathrm{~ms}$ \\
$-71 \mathrm{dBm}$ & 2 detik $496 \mathrm{~ms}$ \\
$-76 \mathrm{dBm}$ & 2 detik $876 \mathrm{~ms}$ \\
$-75 \mathrm{dBm}$ & $2 \operatorname{detik} 820 \mathrm{~ms}$ \\
$-77 \mathrm{dBm}$ & 5 detik $267 \mathrm{~ms}$ \\
$-72 \mathrm{dBm}$ & 2 detik $621 \mathrm{~ms}$ \\
$-77 \mathrm{dBm}$ & 2 detik $948 \mathrm{~ms}$ \\
$-73 \mathrm{dBm}$ & $2 \operatorname{detik} 839 \mathrm{~ms}$ \\
$-79 \mathrm{dBm}$ & 3 detik $283 \mathrm{~ms}$ \\
\hline
\end{tabular}

Hasil uji coba menggunakan koneksi paket data $3 \mathrm{G}$ bisa dilihat pada Tabel 2 atau koneksi $2 \mathrm{G}$ seperti pada Tabel 3. Dari data tersebut dapat dilihat rata-rata response time berada dalam jarak 3-4 detik. Range kekuatan sinyal 3G pada saat uji coba dilakukan adalah $-79 \mathrm{dBm}$ sampai $-75 \mathrm{dBm}$. Sedangkan range kekuatan sinyal $2 \mathrm{G}$ adalah $-79 \mathrm{dBm}$ sampai $-71 \mathrm{dBm}$. Indikator kekuatan sinyal perangkat bergerak untuk ke dua uji coba ini adalah penuh. Hasil uji coba bisa direpresentasikan dalam bentuk grafik seperti pada Gambar 14. Identifikasi menggunakan koneksi Wi-Fi (Intranet) dapat menghemat waktu cukup banyak dibandingkan koneksi $2 \mathrm{G}$ dan $3 \mathrm{G}$. Identifikasi menggunakan koneksi $2 \mathrm{G}$ dan 3G juga dapat digunakan karena hanya membutuhkan waktu sekitar kurang dari 4 detik. Hal lain yang dapat diperhatikan adalah response time menggunakan koneksi $2 \mathrm{G}$ membutuhkan waktu yang lebih sedikit dibandingkan menggunakan koneksi 3G. Ini dapat disebabkan banyak faktor, antara lain seperti kekuatan sinyal, gangguan sinyal pada jaringan $3 \mathrm{G}$ atau $2 \mathrm{G}$.

\subsection{Uji Coba Pengaruh Benda Asing Terha- dap QR Code}

Pada uji coba ini, QR Code yang akan dibaca sebelumnya akan diberikan beberapa gumpalan kecil berupa tisu untuk menutupi sedikit bagian dari QR Code seperti pada Gambar .

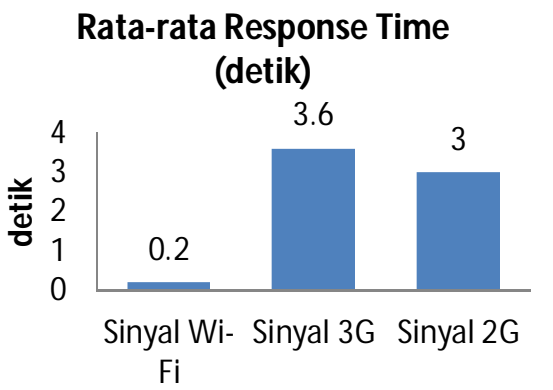

Rata-rata Response Time (detik)

Gambar 14. Rata-rata Response Time

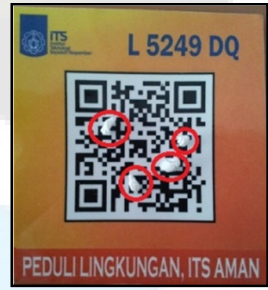

Gambar 15. QRcode yang ditutupi oleh gumpalan tisu

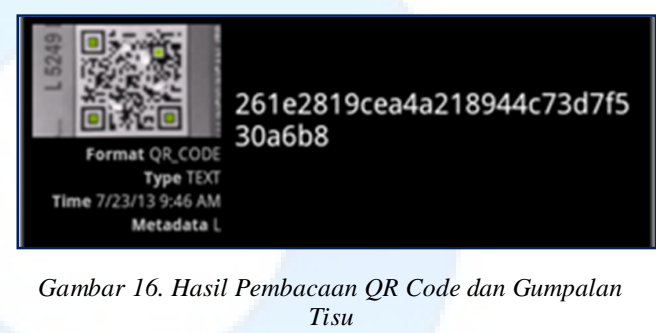

Gumpalan kecil tisu ini mewakili bagian QR Code yang rusak. Tujuan dari uji Coba adalah membuktikan bahwa QR Code masih dapat dibaca walaupun QR Code tersebut mengalami sedikit kerusakan. Gambar 15 menunjukkan bahwa QR Code masih dapat dibaca walaupun ada beberapa bagian dari QR Code yang ditutupi oleh gumpalan kecil berupa tisu (Gambar 16).

\subsection{Uji Coba Pengaruh Air Terhadap QR Code}

Pada uji coba ini, QR Code yang akan dibaca akan diletakkan pada wastafel untuk dialiri air seperti pada Gambar 17. Uji coba ini dilakukan untuk mengetahui kemampuan membaca dan ketaha nan QR Code dalam kondisi hujan. Pada Gambar 18 dapat dilihat bahwa QR Code berhasil dibaca. Hal ini membuktikan QR Code masih dapat dibaca walaupun QR Code tersebut terkena oleh air yang mengalir. 


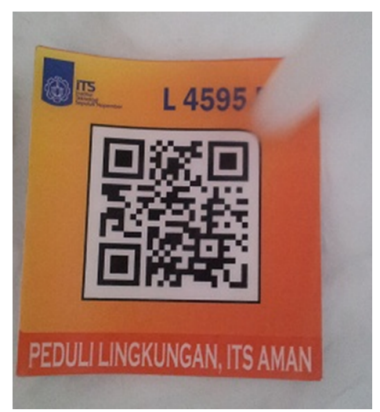

Gambar 17. QR Code yang dibasahi oleh air

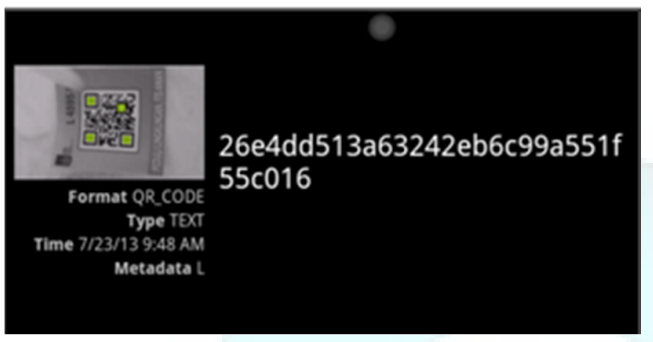

Gambar 18. Hasil Pembacaan QR Code yang dibasahi Air

\subsection{Uji Coba Pengaruh Cahaya Terhadap QR Code}

Pada uji coba kali ini akan dilakukan pembacaan QR Code dengan berbagai kondisi cahaya disekitar. Uji coba menggunakan lingkungan indoor dan outdoor. Hasil dari uji coba digunakan untuk mengetahui pada kondisi apa dan bagaimana QR Code tidak dapat dibaca. Kode untuk TL adalah sinar matahari Tak Langsung, L untuk sinar matahari Langsung, TA untuk Tidak Ada cahaya, dan A adalah Ada cahaya. Berdasarkan uji coba, dapat ditarik kesimpulan bahwa selama masih ada cahaya yang dapat ditangkap oleh QR Code dan kamera, maka proses pembacaan $\mathrm{QR}$ Code masih dapat dilakukan.

\subsection{Uji Coba Pengaruh Jarak Untuk Membaca QR Code}

Pada uji coba kali ini akan dilakukan pembacaan QR Code pada jarak-jarak tertentu. Uji coba dilakukan dengan melakukan pembacaan secara berulang dari jarak terdekat sampai jarak terjauh pada QR Code seperti yang terlihat pada Gambar 19.

Tabel 4. Uji Coba Pengaruh Cahaya Terhadap QR Code

\begin{tabular}{llll}
\hline \multirow{2}{*}{ Ruang } & \multicolumn{2}{c}{ Cahaya } & \multirow{2}{*}{ Terbaca } \\
\cline { 2 - 3 } & Matahari & Lampu & \\
\hline Indoor & $\mathrm{TL}$ & $\mathrm{TA}$ & Ya \\
Indoor & $\mathrm{TL}$ & $\mathrm{A}$ & Ya \\
Outdoor & $\mathrm{L}$ & $\mathrm{TA}$ & Ya \\
Outdoor & $\mathrm{TL}$ & $\mathrm{TA}$ & Ya \\
Indoor & $\mathrm{TA}$ & $\mathrm{A}$ & Ya \\
Indoor & $\mathrm{TA}$ & $\mathrm{TA}$ & Tidak \\
\hline
\end{tabular}

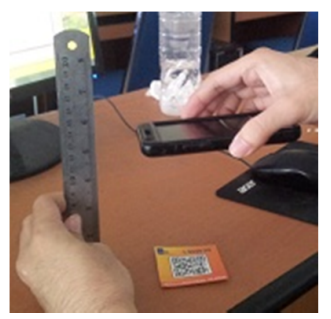

Gambar 19. Mengukur Jarak Baca QR Code

Tabel 5. Uji Coba Pengaruh Jarak Untuk Membaca QR Code

\begin{tabular}{lll}
\hline Percobaan ke & Jarak $(\mathbf{c m})$ & Berhasil \\
\hline 1 & 2 & Tidak \\
2 & 4 & Tidak \\
3 & 6 & Tidak \\
4 & 8 & Tidak \\
5 & 10 & Tidak \\
6 & 12 & Ya \\
7 & 14 & Ya \\
8 & 16 & Ya \\
9 & 18 & Ya \\
10 & 20 & Ya \\
11 & 22 & Ya \\
12 & 24 & Ya \\
13 & 26 & Ya \\
14 & 28 & Ya \\
15 & 30 & Ya \\
16 & 32 & Tidak \\
\hline
\end{tabular}

Berdasarkan Tabel 5, dapat disimpulkan bahwa jarak $2 \mathrm{~cm}$ sampai $10 \mathrm{~cm}$ pembacaan tidak dapat dilakukan, ini disebabkan karena keseluruhan Gambar QR Code belum tertangkap oleh kamera. Sedangkan pada jarak $12 \mathrm{~cm}$ sampai 30 $\mathrm{cm}$ pembacaan QR Code dapat dilakukan dengan baik. Pada jarak $30 \mathrm{~cm}$ ke atas, pembacaan tidak dapat lagi dilakukan, ini dikarenakan QR Code yang tertangkap kamera terlalu kecil, sehingga menyulitkan QR Code untuk dibaca.

\subsection{Uji Coba Implementasi di Lapangan}

Pada implementasi di lapangan dengan uji coba pada sekitar 20 kendaraan pada siang hari, malam hari, dan dalam kondisi QR code basah, rata-rata waktu yang dibutuhkan SKK untuk identifikasi kendaraan dan pengendara dengan menggunakan aplikasi ini adalah sekitar 15 detik. Hal ini jauh lebih cepat daripada metode identifikasi menggunakan STNK. Efektivitas waktu yang didapat sebesar $50 \%$ dan lebih aman karena data kendaraan mulai merk, warna, tipe, nomor kendaraan, foto, bahkan nama pemilik pun bisa ditampilkan. Jika data di aplikasi tidak sesuai dengan data kendaraan, maka bisa dicurigai kendaraan tersebut adalah kendaraan curian. Stiker QR code pun tidak dapat dipalsu dengan mudah karena data plat nomor diberi string rahasia dan masih di-hash dengan fungsi MD5. 


\section{SIMPULAN DAN SARAN}

Berdasarkan implementasi dan sejumlah uji coba yang telah dilakukan, didapatkan beberapa kesimpulan, yaitu:

1. Rata-rata response time aplikasi ITS Identifikasi pada saat menggunakan koneksi Wi-Fi adalah $221.5 \mathrm{~ms}_{\text {s }}$ menggunakan koneksi 3G adalah 3 detik $634 \mathrm{~ms}$, menggunakan koneksi $2 \mathrm{G}$ adalah 3 detik $042 \mathrm{~ms}$.

2. Strategi penyembunyian informasi ID kendaraan pada QR Code dapat dilakukan dengan cara menambahkan string rahasia dan kemudian di-hash menggunakan MD5 untuk menambah tingkat keamanan aplikasi sehingga stiker QR code ini tidak dapat dipalsu pencuri.

3. QR Code masih dapat dibaca walaupun terdapat sedikit kerusakan atau gangguan pada gambar, baik berupa gumpalan tisu atau aliran air.

4. Intensitas cahaya berpengaruh dalam proses pembacaan QR Code. Pada saat gelap maka QR Code tidak dapat dibaca.

5. Jarak efektif untuk membaca QR Code adalah $12 \mathrm{~cm}$ sampai $30 \mathrm{~cm}$
6. Aplikasi mampu mempersingkat waktu identifikasi kendaraan sebanyak $50 \%$ daripada metode identifikasi menggunakan STNK dan memberi informasi kendaraan maupun pengendara dengan lebih detil.

\section{DAFTAR RUJUKAN}

JSON. 2013. Pengenalan JSON. [Online] 2013. [Cited: Juni 24, 2013.] http://www.json.org/json-id.html.

Pala, Zeydin and Inanc, Nihat. 2007. Smart Parking Applications Using RFID Technology. RFID Eurasia. 2007, pp. 1-3.

QR Codes in Education. Law, Chin-ying and So, Simon. 2010. October 2010, Journal of Educational Technology Development and Exchange, Vol. III, pp. 85-100.

Rivest, Ronald. 1992. rfc1321 - The MD5 Message-Digest Algorithm. IETF. [Online] April 1992. http://www.ietf.org/rfc/rfc1321.txt.

Synthesis journal. 2008. s.1.: Information Technology Standards Committee (ITSC), 2008, pp. 59-78. 